\title{
Studies on nitrogenase activity of diazotrophic isolates from different rice production systems
}

\section{S. Kanimoli* and K. Kumar}

Department of Agricultural Microbiology Tamil Nadu Agricultural University, Coimbatore -641003 (Tamil Nadu), INDIA

*Corresponding author. E-mail: kanimicro76@gmail.com

Received: June 12, 2015; Revised received: November 13, 2015; Accepted: February 26, 2016

\begin{abstract}
The present study was carried out to evaluate the nitrogen fixing ability of diazotrophs isolated from the rhizosphere soils of rice which were grown in three different rice growing systems. A total of hundred and ten isolates obtained were subjected to Acetylene Reduction Assay (ARA) and ninety eight isolates recorded significant amount of nitrogenase activity in a range of 185.73 to 3794.55 nmoles of ethylene mg of protein ${ }^{-1} \mathrm{~h}^{-1}$. The highest nitrogenase activity was recorded by Derxia (3794.55 nmoles of ethylene mg of protein ${ }^{-1} \mathrm{~h}^{-1}$ ) isolated from Trichy (lowland). Among the three different rice production systems, isolates obtained from lowland rice (Derxia - 3794.5 nmoles of ethylene $\mathrm{mg}$ of protein ${ }^{-1} \mathrm{~h}^{-1}$ ) recorded higher nitrogenase activity followed by Aerobic (Pseudomonas 2194.89 nmoles of ethylene mg of protein ${ }^{-1} \mathrm{~h}^{-1}$ ) and SRI (Azotobacter - 1971.85 nmoles of ethylene mg of protein $^{-1}$ $\mathrm{h}^{-1}$ ) rice isolates. The results revealed marked variation in the ARA of the diazotrophic isolates obtained from lowland, SRI and Aerobic rice. The nitrogenase activity of diazotrophs from rice fields have been reported earlier but the nitrogenase activity of diazotrophs from three different rice production systems from various parts of Tamil Nadu is reported for the first time from India.
\end{abstract}

Keywords: Acetylene reduction assay, Aerobic, Diazotrophs, Heterotrophs, Lowland

\section{INTRODUCTION}

Rice is the most important cereal crop. The primary source of rice is from Asia and India and also rainfed rice cultivation have been popular for about five thousand years. Rice after wheat is the most important crop and has a very valuable role in feeding people in the world. In the next three decades, the world will need to produce about $60 \%$ more rice than today's global production to feed the extra billion people. Biological nitrogen fixations (BNF) by diazotrophs play a significant role in nitrogen cycling and have drawn the attention of researchers because they represent one of the largest sources of nitrogen input to soil. Diazotrophs are present in the aerobic soil layers, rhizosphere, roots and stem bases of rice agro-ecosystems. They have the capacity to fix molecular nitrogen under microaerophilic conditions as a growth promoting substrate in nitrogen deficient environment. All the known diazotrophs possess nifH gene, which encodes the iron protein subunit of nitrogenase enzyme, and has been frequently used as a molecular marker to detect diazotrophs in environmental samples (Sarkar et al., 2014).

Nitrogen is the major nutrient limiting the high yield potential of modern rice cultivars. Development of fertilizer responsive varieties, coupled with the realization by farmers of the importance of nitrogen, has led to high rates of $\mathrm{N}$ fertilizer use on rice. But unfortunately a substantial amount of the $\mathrm{N}$ fertilizer is lost through different mechanisms causing environmental pollution problems (Rangjaroen et al., 2015). Utilization of biological $\mathrm{N}$ fixation (BNF) technology can decrease the use of $\mathrm{N}$ fertilizer, reducing the environmental problems to a considerable extent. BNF technologies must be economically viable, ecologically sound, and socially acceptable to be successful (Ladha and Reddy, 2003). In agricultural soils, except for anthropogenic sources, diazotrophic communities are the main source of nitrogen. Biological fixation offers a non-polluting source of nitrogen and could improve crop production and decrease the global use of synthetic fertilizers. Nonsymbiotic bacterial diazotrophs can promote economic and environmental benefits including increased income from high yields, reduced fertilizer costs and reduced emissions of the greenhouse gas $\mathrm{N}_{2} \mathrm{O}$, as well as reduced leaching of $\mathrm{NO}_{3}$ to ground water (Kennedy et al., 2004). Diazotrophic bacteria are known to directly and indirectly affect plant growth, directly through a substantial contribution of BNF to $\mathrm{N}$ acquisition of the plant and indirectly through the synthesis and export of organic substances like phytohormones that enhance root growth. The free -living and plant associated bacteria are ubiquitous in soil, but there are little understanding of their diversity and contribution to $\mathrm{N}$-input. The objective of this present study was to isolate and identify diazotrophic bacteria from the rhizosphere of rice from different loca- 
tion and different rice production systems viz., Lowland, SRI and Aerobic.

\section{MATERIALS AND METHODS}

Collection of soil sample: The rhizosphere soil samples were collected from five different locations in Tamil Nadu viz., Coimbatore (Thondamuthur - Ikaraipoluvampatty, Saadivayal and Muttathuvayal), Pollachi (Kottur, Somandurai and Ponnapuram), Aduthurai (Melamaruthuvakudi, Kelamaruthuvakudi and Avainyapuram), Trichy (Poovalur, Vaaladi and Maandurai) and Killilulam (Morappanadu, Naanalkadu and Kongaraiyarkuruchi). Rhizosphere soil samples were collected carefully by uprooting the root system and placed in a cool box for transport and stored at $4{ }^{0} \mathrm{C}$.

Isolation of diazotrophic bacteria from rhizosphere soil: Diazotrophic bacteria were enumerated and isolated by following standard plate count method (Allen, 1953). The different $\mathrm{N}$ free media used were Waksman No 77 medium for Azotobacter, Becking's medium (Becking,1961) for Beijerinckia, Nitrogenfree glucose mineral medium for Derxia
(Becking,1981) and King's B medium (King et al., 1954) for Pseudomonas. In case of Azospirillum Most Probable Number (MPN) technique (Cochran, 1950) was followed by using Nitrogen free malic acid semi solid medium (Dobereiner, 1980).

One gram of soil from each sample was aseptically weighed, transferred to $100 \mathrm{ml}$ sterile water blank and shaken $(120 \mathrm{rpm})$ for $30 \mathrm{~min}$ to get $10^{-2}$ dilution. After thorough shaking, one $\mathrm{ml}$ of diluent from $10^{-2}$ dilution was transferred to $9 \mathrm{ml}$ water blank to get $10^{-3}$ dilution. Likewise, the sample was diluted serially with $9 \mathrm{ml}$ water blanks until the appropriate dilution was obtained. Aliquots $(1 \mathrm{ml})$ from the serially diluted samples $\left(10^{-3}\right.$ to $\left.10^{-6}\right)$ were added to five different $\mathrm{N}$-free media in Petri plates and kept in an incubator at $30^{\circ} \mathrm{C}$ for isolation.

Purification and labelling of isolates: Colonies with similar colony characters were grouped according to their morphological characteristics. Single colonies were picked from the Petri dishes and sub-cultured several times to obtain pure cultures. Stock cultures were made in nutrient broth containing $50 \%(\mathrm{w} / \mathrm{v})$ glycerol and stored at $-80^{\circ} \mathrm{C}$.

Table 1. Acetylene reduction assay of Azospirillum from different rice growing areas in Tamil Nadu.

\begin{tabular}{|c|c|c|c|c|c|}
\hline S.N. & $\begin{array}{l}\text { Rice produc- } \\
\text { tion system }\end{array}$ & Location & Village & Strain Name & $\begin{array}{l}\text { ARA activity } \\
\left(\text { moles of } \mathrm{C}_{2} \mathrm{H}_{4}\right. \\
\mathrm{mg}^{-1} \text { protein } \mathrm{h}^{-1} \text { ) }\end{array}$ \\
\hline 1. & Aerobic & Coimbatore (Pollachi) & Ponnapuram & $A s \mathrm{AC}_{2} \mathrm{P}_{1}-1$ & 717.8 \\
\hline 2. & SRI & Killikulam & Naanalkadu & AsSKN & 1056.9 \\
\hline 3. & $\begin{array}{l}\text { Azospirillum } \\
(\mathrm{Az}-204)\end{array}$ & & & & 658.6 \\
\hline 4. & Lowland & Aduthurai & Melamaruthuvakudi & $A s \mathrm{LAM}_{2}-1$ & 1461.0 \\
\hline 5. & Lowland & Coimbatore (Pollachi) & Kottur & $A s \mathrm{LC}_{2} \mathrm{~K}_{1}-1$ & 756.2 \\
\hline 6. & Aerobic & Trichy & Maandurai & As $\mathrm{ATM}_{3}-1$ & 1187.3 \\
\hline 7. & Lowland & Coimbatore (Pollachi) & Kottur & $\mathrm{AsLC}_{2} \mathrm{~K}_{1}-2$ & 1476.3 \\
\hline 8. & SRI & Trichy & Vaaladi & $A s \mathrm{STV}-1$ & 900.4 \\
\hline 9. & Lowland & Trichy & Poovalur & $A s \mathrm{LTP}-1$ & 482.9 \\
\hline 10. & Lowland & $\begin{array}{l}\text { Coimbatore } \\
\text { (Thondamuthur) }\end{array}$ & Ikaraipoluvampatty & $A s \mathrm{LC}_{1} \mathrm{I}-1$ & 1584.3 \\
\hline 11. & Lowland & Trichy & Poovalur & AsLTP -2 & 1609.3 \\
\hline 12. & SRI & Coimbatore (Thondamuthur & Saadivayal & $A s \mathrm{SC}_{1} \mathrm{~S}_{1}$ & 907.5 \\
\hline 13. & Aerobic & Coimbatore (Pollachi) & Ponnapuram & As $\mathrm{AC}_{2} \mathrm{P}_{1}-1$ & 361.6 \\
\hline 14. & Lowland & Coimbatore (Thondamuthur) & Ikaraipoluvampatty & $A s \mathrm{LC}_{1} \mathrm{I}-1$ & 577.7 \\
\hline 15. & Aerobic & Trichy & Maandurai & As $\mathrm{ATM}_{3}-2$ & 877.6 \\
\hline 16. & Aerobic & Coimbatore (Pollachi) & Ponnapuram & As $\mathrm{AC}_{2} \mathrm{P}_{1}-2$ & 730.3 \\
\hline 17. & Aerobic & Coimbatore (Pollachi) & Ponnapuram & As $\mathrm{AC}_{2} \mathrm{P}_{1}-3$ & 519.7 \\
\hline 18. & Aerobic & Coimbatore (Thondamuthur) & Muttathuvayal & As $\mathrm{AC}_{2} \mathrm{M}_{1}-4$ & 589.1 \\
\hline 19. & Aerobic & Coimbatore (Thondamuthur) & Muttathuvayal & $A s \mathrm{AC}_{2} \mathrm{M}_{1}-5$ & 863.0 \\
\hline 20. & Aerobic & Killikulam & Kongaraiyarkuruchi & As $\mathrm{AKK}_{3}$ & 1416.4 \\
\hline 21. & Lowland & Killikulam & Morappanadu & $A s \mathrm{LKM}_{4}$ & 821.3 \\
\hline 22. & Aerobic & Trichy & Maandurai & As $\mathrm{ATM}_{3}-3$ & 902.0 \\
\hline 23. & Lowland & Aduthurai & Melamaruthuvakudi & $A s \mathrm{LAM}_{2}-2$ & 588.5 \\
\hline 24. & SRI & Trichy & Vaaladi & $A s \mathrm{STV}-2$ & 591.1 \\
\hline \multirow[t]{3}{*}{25.} & Aerobic & Aduthurai & Avainyapuram & As $\mathrm{AA}_{1} \mathrm{~A}_{2}$ & 552.3 \\
\hline & SEd & & & & 39.1 \\
\hline & $\mathrm{CD}(\mathrm{P}=0.05)$ & & & & 78.6 \\
\hline
\end{tabular}


Determination of nitrogenase activity of the isolates: The nitrogen fixing capacity of the isolates was evaluated for 115 diazotrophic isolates by Acetylene Reduction Assay in the Gas Chromatograph (Chemito GC 7610) following the standard procedure (Burris, 1974). Twenty five $\mathrm{ml}$ of the respective broth was dispensed in $100 \mathrm{ml}$ vials and sterilized. One $\mathrm{ml}$ of standard inoculum of the isolated cultures were added to the vials, mixed well and incubated for $72 \mathrm{hrs}$. Then cotton plugs were replaced with rubber stoppers and fixed with aluminum caps. Seventy five $\mathrm{ml}$ of air from the head space of the vial was withdrawn and nitrogen gas was flushed to remove the excess oxygen and $5 \mathrm{ml}$ of pure acetylene gas were injected into the vial which was incubated at $37^{\circ} \mathrm{C}$ for $48 \mathrm{hrs}$. After incubation period, $0.2 \mathrm{ml}$ of gas sample was withdrawn using a sterile disposable microsyringe and injected into the gas chromatograph fitted with a poropak Q column and FID detector. The column temperature was maintained at $120^{\circ} \mathrm{C}$ and injector and detector temperature were maintained at $150^{\circ} \mathrm{C}$. The peak height was measured and nitrogenase activity was estimated and expressed as $\mathrm{n}$ moles of ethylene formed $\mathrm{h}^{-1} \mathrm{mg}^{-1}$ protein. Those cultures, which showed high nitrogenase activity, were selected for further studies.
Statistical analysis: Results of the measurements were subjected to analysis of variance (ANOVA) and significance at the $5 \%$ level was tested by Least Significant Difference (LSD) using SAS package, Version 8.2 (SAS, 2001).

\section{RESULTS AND DISCUSSION}

Isolation of diazotrophs from rice rhizosphere soil: The different diazotrophic population was isolated from rhizosphere soil of rice at different locations of Tamil Nadu. The current investigation demonstrated that the diazotrophs thrived well with maximum numbers in the rhizosphere soil of rice isolated from different locations of Tamil Nadu. Among the diazotrophs, population of Pseudomonas was found to be maximum followed by Azospirillum and Azotobacter. Kumar and Sugitha (2004) reported that the proportion of total diazotrophs to total heterotrophs was in the range of 12.39 to $20.65 \%$ in the rhizosphere of different rice cultivars and the distribution pattern of these diazotrophs was in the order of Pseudomonas $>$ Azospirillum $>$ Azotobacter $>$ Beijerinckia $>$ Derxia $>$ Klebsiella $>$ Enterobacter. The results of the present study are in conformity with earlier findings of Kumar and Sugitha. This high proportion of the diazotrophs in

Table 2. Acetylene reduction assay of Azotobacter from different rice growing areas in Tamil Nadu.

\begin{tabular}{|c|c|c|c|c|c|}
\hline S.N. & $\begin{array}{l}\text { Rice produc- } \\
\text { tion system }\end{array}$ & Location & Village & Strain Name & $\begin{array}{l}\text { ARA activity } \\
\left(\text { nmoles of } \mathrm{C}_{2} \mathrm{H}_{4}\right. \\
\left.\mathrm{mg}^{-1} \text { protein } \mathrm{h}^{-1}\right)\end{array}$ \\
\hline 1. & Aerobic & Trichy & Maandurai & $\mathrm{AbATM}_{3}$ & 737.3 \\
\hline 2. & Aerobic & Aduthurai & Avainyapuram & $A b \mathrm{AA}_{1} \mathrm{~A}_{2}-1$ & 1740.4 \\
\hline 3. & Lowland & Aduthurai & Melamaruthuvakudi & $A b \mathrm{LAM}_{2}-1$ & 782.3 \\
\hline 4. & Lowland & Aduthurai & Melamaruthuvakudi & $A b \mathrm{LAM}_{2}-2$ & 361.5 \\
\hline 5. & Lowland & Coimbatore (Thondamuthur) & Ikaraipoluvampatty & $A b \mathrm{LC}_{1} \mathrm{I}-1$ & 1047.7 \\
\hline 6. & SRI & Aduthurai & Kelamaruthuvakudi & $A b \mathrm{SA}_{1} \mathrm{~K}_{2}-1$ & 681.8 \\
\hline 7. & Aerobic & Coimbatore (Pollachi) & Ponnapuram & $A b \mathrm{AC}_{2} \mathrm{P}_{1}-1$ & 1018.0 \\
\hline 8. & Aerobic & Coimbatore (Pollachi) & Ponnapuram & $A b \mathrm{AC}_{2} \mathrm{P}_{1}-2$ & 394.4 \\
\hline 9. & Aerobic & Coimbatore (Pollachi) & Ponnapuram & $A b \mathrm{AC}_{2} \mathrm{P}_{1}-3$ & 764.4 \\
\hline 10. & Aerobic & Coimbatore (Pollachi) & Ponnapuram & $A b \mathrm{AC}_{2} \mathrm{P}_{1}-4$ & 512.6 \\
\hline 11. & Aerobic & Aduthurai & Avainyapuram & $A b \mathrm{AA}_{1} \mathrm{~A}_{2}-2$ & 627.4 \\
\hline 12. & Lowland & Coimbatore Thondamuthur) & Ikaraipoluvampatty & $A b \mathrm{LC}_{1} \mathrm{I}-2$ & 863.7 \\
\hline 13. & Lowland & Aduthurai & Melamaruthuvakudi & $A b \mathrm{LAM}_{2}-3$ & 1422.2 \\
\hline 14. & SRI & Aduthurai & Kelamaruthuvakudi & $A b_{1} \mathrm{~K}_{2}-2$ & 1327.9 \\
\hline 15. & SRI & Coimbatore (Thondamuthur & Saadivayal & $A b \mathrm{SC}_{1} \mathrm{~S}_{1}$ & 1480.6 \\
\hline 16. & Lowland & Trichy & Poovalur & $A b \mathrm{LTP}-1$ & 1543.6 \\
\hline 17. & SRI & Trichy & Vaaladi & $A b \mathrm{STV}$ & 1508.0 \\
\hline 18. & SRI & Killikulam & Naanalkadu & $A b \mathrm{SKN}$ & 1971.8 \\
\hline 19. & Lowland & Trichy & Poovalur & $A b \mathrm{LTP}-2$ & 2463.1 \\
\hline 20. & Lowland & $\begin{array}{l}\text { Coimbatore } \\
\text { (Thondamuthur) }\end{array}$ & Ikaraipoluvampatty & $A b \mathrm{LC}_{1} \mathrm{I}-3$ & 1320.0 \\
\hline 21. & Aerobic & Killikulam & Kongaraiyarkuruchi & $\mathrm{AbAKK}_{3}$ & 376.3 \\
\hline \multirow[t]{3}{*}{22.} & $\begin{array}{l}\text { Azotobacter } \\
\text { chroococcum }\end{array}$ & & & & 647.6 \\
\hline & SEd & & & & 48.8 \\
\hline & $\mathrm{CD}(\mathrm{P}=0.05)$ & & & & 98.4 \\
\hline
\end{tabular}


Table 3. Acetylene reduction assay of Beijerinckia from different rice growing areas in Tamil Nadu.

\begin{tabular}{|c|c|c|c|c|c|}
\hline S.N. & $\begin{array}{l}\text { Rice produc- } \\
\text { tion system }\end{array}$ & Location & Village & Strain Name & $\begin{array}{l}\text { ARA activity } \\
\left(\mathrm{nmoles}^{-1} \mathrm{C}_{2} \mathrm{H}_{4}\right. \\
\left.\mathrm{mg}^{-1} \text { protein } \mathrm{h}^{-1}\right)\end{array}$ \\
\hline 1. & Aerobic & Trichy & Maandurai & $\mathrm{BeATM}_{3}-1$ & 438.4 \\
\hline 2. & SRI & Coimbatore (Thondamuthur) & Saadivayal & $\mathrm{BeSC}_{1} \mathrm{~S}_{1}$ & 1702.4 \\
\hline 3. & SRI & Killikulam & Naanalkadu & $B e S K N$ & 695.0 \\
\hline 4. & Aerobic & Aduthurai & Avainyapuram & $B e \mathrm{AA}_{1} \mathrm{~A}_{2}$ & 1180.8 \\
\hline 5. & SRI & Coimbatore (Pollachi) & Somandurai & $\mathrm{BeSC}_{2} \mathrm{~S}_{2}$ & 1806.2 \\
\hline 6. & Lowland & Trichy & Poovalur & BeLTP -1 & 750.1 \\
\hline 7. & Aerobic & Killikulam & Kongaraiyarkuruchi & $\mathrm{BeAKK}_{3}$ & 185.7 \\
\hline 8. & Aerobic & Coimbatore (Thondamuthur) & Muttathuvayal & $B e \mathrm{AC}_{2} \mathrm{M}_{1}$ & 1810.6 \\
\hline 9. & SRI & Trichy & Vaaladi & BeSTV & 211.1 \\
\hline 10. & Aerobic & Trichy & Maandurai & $\mathrm{BeATM}_{3}-1$ & 539.6 \\
\hline 11. & Lowland & Trichy & Poovalur & BeLTP -2 & 625.5 \\
\hline 12. & Lowland & Killikulam & Morappanadu & $\mathrm{BeLKM}_{4}$ & 315.9 \\
\hline 13. & Aerobic & Coimbatore (Pollachi) & Ponnapuram & $\mathrm{BeAC}_{2} \mathrm{P}_{1}$ & 1613.1 \\
\hline 14. & Lowland & Coimbatore (Thondamuthur) & Ikaraipoluvampatty & $B e \mathrm{LC}_{1} \mathrm{I}$ & 1716.3 \\
\hline \multirow[t]{3}{*}{15.} & Lowland & Aduthurai & Melamaruthuvakudi & $\mathrm{BeLAM}_{2}$ & 364.3 \\
\hline & SEd & & & & 45.5 \\
\hline & $\mathrm{CD}(\mathrm{P}=0.05)$ & & & & 92.9 \\
\hline
\end{tabular}

the rhizosphere may be due the beneficial influence of root exudates. The findings of Xie and Yokota (2004) have specified that the number of nitrogen fixers is strongly governed by soil organic matter content, and is not significantly affected by water.

Nitrogenase activity of diazotrophs isolated from rhizosphere soil of rice: The confirmation test for nitrogen fixing ability was done by gas chromatographic analysis by acetylene reduction assay and the results are furnished in (Tables 1- 5).

A total of hundred and fifteen isolates obtained were subjected to Acetylene Reduction Assay (ARA) and ninety eight isolates recorded significant amount of nitrogenase activity in the range of 185.7 to 3794.6 nmoles of ethylene mg of protein ${ }^{-1} \mathrm{~h}^{-1}$. Maximum nitrogenase activity was recorded by Derxia ( 3794.5 nmoles of ethylene mg of protein ${ }^{-1} \mathrm{~h}^{-1}$ ) isolated from Trichy (lowland). Among the three different rice production systems, isolates obtained from lowland rice (Derxia - 3794.5 nmoles of ethylene $\mathrm{mg}$ of protein ${ }^{-1} \mathrm{~h}^{-1}$ ) recorded higher nitrogenase activity followed by Aerobic rice isolate (Pseudomonas - 2194.9 nmoles of ethylene mg of protein $\left.{ }^{-1} \mathrm{~h}^{-1}\right)$ and SRI rice isolate (Azotobacter - 1971.9 nmoles of ethylene $\mathrm{mg}$ of protein $\left.^{-1} \mathrm{~h}^{-1}\right)$. The results revealed marked variation in the ARA of the diazotrophic isolates obtained from lowland, SRI and Aerobic rice.

The discovery that the nitrogenase enzyme responsible for nitrogen fixation also reduced $\mathrm{C}_{2} \mathrm{H}_{2}$ to $\mathrm{C}_{2} \mathrm{H}_{4}$ (Dilworth, 1966), a useful assay for the quantification of the nitrogen fixation process. For quantitative determinations of nitrogen fixation, ${ }^{15} \mathrm{~N}_{2}$ techniques should be used, however, the acetylene reduction assay is still used widely, because it provides a highly sensitive and inexpensive way to quantify relative nitrogenase enzyme activity in nitrogen fixing samples.

Diazotrophic bacteria varied in acetylene reduction, which is an indirect measure of $\mathrm{N}$-fixing potential while also being a specific means for monitoring of functional nitrogenase activity (Andrade et al., 1997 and Park et al., 2005).

All the 115 diazotrophic isolates were subjected to acetylene reduction assay out of which 99 isolates were able to fix atmospheric dinitrogen. The high acetylene reduction was recorded in the isolate DeLTP with $3794.5 \mathrm{n}$ moles of ethylene $\mathrm{mg}^{-1}$ protein $\mathrm{h}^{-1}$. This was confirmed by Keyeo et al. (2011) that diazotrophs have the ability to fix atmospheric nitrogen. Flooding the soil cuts off its oxygen supply. During the succession of anaerobic oxidation processes, the redox potential (Eh) of flooded soils will decrease as a result of the reduced products formed. Oxygen is depleted soon after flooding. Within a few hours, soil organisms use up the trapped oxygen and render the soil anaerobic. To grow and ward off toxins, which are present in anaerobic soils, rice has evolved a genetically fixed system of transporting oxygen from shoot to roots. The system is only lightly less efficient in upland than in lowland rice (Huang et al., 2012). This remarkable characteristic of rice operates to its disadvantage when it is grown in aerobic soils. Some strains isolated in this study showed relatively low ARA. Firstly, this could have been because the oxygen level was not controlled when incubating, and diazotrophs have a varying ability to tolerate oxygen (Barber and Evans, 1976; Postgate, 1998). Secondly, nitrogenase activity de- 
Table 4. Acetylene reduction assay of Derxia from different rice growing areas in Tamil Nadu.

\begin{tabular}{|c|c|c|c|c|c|}
\hline S.N. & $\begin{array}{l}\text { Rice produc- } \\
\text { tion system }\end{array}$ & Location & Village & Strain Name & $\begin{array}{l}\text { ARA activity } \\
\left(\mathrm{nmoles} \text { of } \mathrm{C}_{2} \mathrm{H}_{4}\right. \\
\left.\mathrm{mg}^{-1} \text { protein } \mathrm{h}^{-1}\right)\end{array}$ \\
\hline 1. & Lowland & Trichy & Poovalur & DeLTP -1 & 551.6 \\
\hline 2. & Lowland & Trichy & Poovalur & DeLTP -2 & 3794.5 \\
\hline 3. & Aerobic & Coimbatore (Pollachi) & Ponnapuram & $D e \mathrm{AC}_{2} \mathrm{P}$ & 1821.0 \\
\hline 4. & Lowland & Aduthurai & Melamaruthuvakudi & $\mathrm{DeLAM}_{2}$ & 965.4 \\
\hline 5. & Aerobic & Trichy & Maandurai & $\operatorname{DeATM}_{3}-1$ & 1913.1 \\
\hline 6. & Lowland & Coimbatore (Thondamuthur) & Ikaraipoluvampatty & $D e \mathrm{LC}_{1} \mathrm{I}$ & 512.1 \\
\hline 7. & Lowland & Killikulam & Morappanadu & $\mathrm{DeLKM}_{4}$ & 621.3 \\
\hline 8. & Aerobic & Aduthurai & Avainyapuram & $D e \mathrm{AA}_{1} \mathrm{~A}_{2}$ & 2055.5 \\
\hline 9. & Aerobic & Trichy & Maandurai & $\mathrm{DeATM}_{3}-2$ & 966.9 \\
\hline 10. & SRI & Aduthurai & Kelamaruthuvakudi & $\mathrm{DeSA}_{1} \mathrm{~K}_{2}$ & 1078.1 \\
\hline 11. & SRI & Trichy & Vaaladi & DeSTV & 891.7 \\
\hline 12. & SRI & Killikulam & Naanalkadu & DeSKN & 1211.5 \\
\hline 13. & SRI & Coimbatore (Thondamuthur) & Saadivayal & $\operatorname{DeSC}_{1} \mathrm{~S}_{1}$ & 1358.8 \\
\hline 14. & Aerobic & Coimbatore (Thondamuthur) & Muttathuvayal & $\mathrm{DeAC}_{2} \mathrm{M}_{1}$ & 467.8 \\
\hline \multirow[t]{3}{*}{15.} & SRI & \multirow[t]{3}{*}{ Coimbatore (Pollachi) } & \multirow[t]{3}{*}{ Somandurai } & \multirow[t]{3}{*}{$\mathrm{DeSC}_{2} \mathrm{~S}_{2}$} & 543.1 \\
\hline & SEd & & & & 61.5 \\
\hline & $\mathrm{CD}(\mathrm{P}=0.05)$ & & & & 125.7 \\
\hline
\end{tabular}

Table 5. Acetylene reduction assay of Pseudomonas from different rice growing areas in Tamil Nadu.

\begin{tabular}{|c|c|c|c|c|c|}
\hline S.N. & $\begin{array}{l}\text { Rice production } \\
\text { system }\end{array}$ & Location & Village & Strain Name & $\begin{array}{l}\text { ARA activity } \\
\left(\mathrm{nmoles}^{-} \mathrm{C}_{2} \mathrm{H}_{4}\right. \\
\left.\mathrm{mg}^{-1} \text { protein } \mathrm{h}^{-1}\right)\end{array}$ \\
\hline 1. & SRI & Coimbatore (Thondamuthur) & Saadivayal & $P s \mathrm{SC}_{1} \mathrm{~S}_{1}$ & 1368.7 \\
\hline 2. & Lowland & Aduthurai & Melamaruthuvakudi & $P s \mathrm{LAM}_{2}-1$ & 2401.7 \\
\hline 3. & Aerobic & Aduthurai & Avainyapuram & $\operatorname{Ps} \mathrm{AA}_{1} \mathrm{~A}_{2}-1$ & 1249.8 \\
\hline 4. & SRI & Coimbatore (Pollachi) & Somandurai & $\mathrm{PsSC}_{2} \mathrm{~S}_{2}$ & 837.1 \\
\hline 5. & Aerobic & Coimbatore Thondamuthur) & Muttathuvayal & $P s \mathrm{AC}_{2} \mathrm{M}_{1}$ & 1054.7 \\
\hline 6. & Aerobic & Trichy & Maandurai & $P s \mathrm{ATM}_{3}-1$ & 466.0 \\
\hline 7. & Lowland & Aduthurai & Melamaruthuvakudi & $P s \mathrm{LAM}_{2}-2$ & 760.3 \\
\hline 8. & SRI & Killikulam & Naanalkadu & PsSKN & 700.9 \\
\hline 9. & Lowland & Aduthurai & Melamaruthuvakudi & $P s \mathrm{LAM}_{2}-3$ & 1112.5 \\
\hline 10. & Aerobic & Trichy & Maandurai & Ps $\mathrm{ATM}_{3}-2$ & 941.3 \\
\hline 11. & SRI & Trichy & Vaaladi & PsSTV & 1038.9 \\
\hline 12. & Lowland & Trichy & Poovalur & PsLTP -1 & 576.4 \\
\hline 13. & Lowland & Killikulam & Morappanadu & $P_{s} \mathrm{LKM}_{4}$ & 774.4 \\
\hline 14. & Lowland & Trichy & Poovalur & PsLTP - 2 & 1023.1 \\
\hline 15. & SRI & Aduthurai & Kelamaruthuvakudi & $P s \mathrm{~A}_{1} \mathrm{~K}_{2}-1$ & 1452.1 \\
\hline 16. & Lowland & Trichy & Poovalur & PsLTP - 3 & 635.6 \\
\hline 17. & SRI & Aduthurai & Kelamaruthuvakudi & $P s \mathrm{~A}_{1} \mathrm{~K}_{2}-2$ & 574.0 \\
\hline 18. & $\begin{array}{l}\text { Pseudomonas fluo- } \\
\text { rescence (Standard) }\end{array}$ & & & & 1498.1 \\
\hline 19. & Aerobic & Aduthurai & Avainyapuram & Ps $\mathrm{AA}_{1} \mathrm{~A}_{2}-2$ & 829.8 \\
\hline 20. & Aerobic & Coimbatore (Pollachi) & Ponnapuram & $P s \mathrm{AC}_{2} \mathrm{P}$ & 2194.8 \\
\hline 21. & Aerobic & Aduthurai & Avainyapuram & $P s \mathrm{AA}_{1} \mathrm{~A}_{2}-3$ & 428.5 \\
\hline \multirow[t]{3}{*}{22.} & Lowland & Coimbatore (Thondamuthur) & Ikaraipoluvampatty & $P s \mathrm{LC}_{1} \mathrm{I}$ & 631.1 \\
\hline & SEd & & & & 46.5 \\
\hline & $\mathrm{CD}(\mathrm{P}=0.05)$ & & & & 93.8 \\
\hline
\end{tabular}


creases when nitrogen fixing bacteria are purified and cultured. Thirdly, diazotrophs show different nitrogen fixing ability when the composition of the cultural media is changed (Dobereiner, 1989). This was supported by a study (Shrestha et al., 2007), which revealed that among all the carbon sources, almost all the diazotrophs preferred glucose for high nitrogen fixing activity and some preferred sucrose and other carbon sources like mannitol.

\section{Conclusion}

All the 115 isolates obtained from the rhizosphere of rice grown in three different production systems in different rice growing areas of Tamil Nadu were subjected to morphological and biochemical characterization for preliminary identification of isolates. All the isolates were Gram negative. In case of Azospirillum, the cells were spirillum and in Azotobacter some cells are found to be pleomorphic. The Pseudomonas isolates produced fluorescein pigment. Out of 115 diazotrophic isolates, 99 isolates recorded significant amount of nitrogenase activity in a range of 185.7 to 3794.5 nmoles of ethylene mg of protein ${ }^{-1} \mathrm{~h}^{-1}$. The maximum nitrogenase activity was exhibited by isolate DeLTP (3794.5 nmoles of ethylene mg of protein ${ }^{-1} \mathrm{~h}^{-}$ $\left.{ }^{1}\right)$. The nitrogenase activity of diazotrophs from rice fields have been reported earlier but the nitrogenase activity of diazotrophs from three different rice production systems from various parts of Tamil Nadu was novelty of study reported first time from India.

\section{REFERENCES}

Allen, E.K. (1953). Experiments in soil microbiology. Burgess Publ. C., Minnepolis, Minn., pp: 107

Andrade, G. Esteban, E. Velascol, L. Maria, J.L. and Bedmar, E.J.(1997). Isolation and identification of $\mathrm{N}_{2}$-fixing microorganisms from the rhizosphere of Capparis spinosa (L.). Plant Soil. 197:19 - 23.

Barber, L.E. and Evans, H.J.(1976). Characterization of a nitrogen-fixing bacterial strain from the roots of Digitaria sanguinalis. Can. J. Microbiol. 22: 254-260.

Becking,J.H.(1961).Studies on nitrogen - fixing bacteria of the genus Beijerinckia I. Geographical and ecological distribution in soils. Plant Soil. 14: 49-81.

Becking, J.H.(1981). The family Azotobacteraceae. In: Ballows, A., Truper, H.G., Dworkin, M., Harder, W., Schleifer, K.H. (Eds.), The Procaryotes: A Handbook on Habitats, Isolation, and Identification of Bacteria, Springer, Heidelberg, pp. 795-817.

Burris, R.H. (1974). Methodology. In Biology of nitrogen fixation. Ed. A. Quispel. pp. 3 -42. North Holland P Burris R H 1974 Methodology. In Biology of Nitrogen Fixation. Ed. A. Quispel. pp. 3-42. North Holland Publishing Co., Amsterdam.ublishing Co., Amsterdam.
Cochran, W.G. (1950). Estimation of bacterial densities by means of the most probable number. Biometrics. 6: 105-116.

Dilworth, M.J. (1966). Acetylene reduction by nitrogen fixing preparations from Clostridium pasteurianum. Biochem. Biophys. Acta. 127: 285-294.

Dobereiner, J. (1980). Forage grasses and grain crops. In Methods for Evaluation of Biological Nitrogen Fixation, pp. 535-555. Edited by J. F. J. Bergersen. Chichester: Wiley.

Dobereiner, J. (1989). Isolation and identification of root associated diazotrophs. In: Nitrogen fixation with nonlegumes. (Eds.) F.A. Skinner Kluwer and Dordrecht, Kluwer Academic Publ., Dordrecht. pp.125 -176.

Huang, X. Kurata, N. Wei, X. Wang, Z.X. Wang, A. Zhao, Q. Zhao, Y. Liu, K.(2012). A map of rice genome variation reveals the origin of cultivated rice. Nature. 490: 497-501.

Kennedy,I.R. Choudhury, A.T.M.A. and Kecskés, M.L. (2004). Non-symbiotic diazotrophs in crop-farming systems: can their potential for plant growth promotion be better exploited? Soil Biol. Biochem. 36: 1229 -1244.

Keyeo, F.O. Aishah, N. and Amir, H.G. (2011). The effects of Nitrogen fixation Activity and Phytohormone Production of Diazotroph in Promoting Growth of Rice seedlings. Biotechnology. 10: 267 - 273.

King,J.W. Ward, M. K. and Raney, D. E. (1954). Two simple media for the demonstration of pyocyanin and fluorescein. $J$. Lab and Clin. Med. 44: 301-307.

Kumar, K. and Sugitha,T.C.K.. (2004). Diazotrophic diversity in rice ecosystem. In: Paper presented in the International symposium on Microbial Ecology, Aug 22-27.

Ladha, J.K and Reddy, P.M. (2003). Nitrogen fixation in rice systems: State of knowledge and future prospects. Plant Soil. 252:151-167.

Park, M. C. Kin, J. Yang, H. Lee, W. Shin, S. Kim, and Sa,T. (2005). Isolation and characterization of diazotrophic growth promoting bacteria from rhizosphere of agricultural crops of Korea. Microbiol. Res. 160: 127-133.

Postgate, J. (1998). Nitrogen fixation, $3^{\text {rd }}$ edn. Cambridge University Press, Cambridge.

Rangjaroen,C. Rerkasem, B. Teaumroong, N. Noidsangiam, R. Lumyong, S. (2015). Promoting plant growth in a commercial rice cultivar by endophytic diazotrophic bacteria isolated from rice land races. Ann.Microbiol. 65: $253-266$

Sarkar,A. Manjunath, K. and Vishwakarma , P. (2014). Diversity of Diazotrophs in tropical rice field under the influence of organic and nitrogen fertilization. Ind.J.Biotecnol.13: 540 - 543 .

Shrestha, A. Toyota,K. Okazaki,M. Suga,Y. Quevedo,M.A. Loreto,A.B. and Mariscal, A.A. (2007). Enhancement of nitrogen-fixing activity of enterobacteriaceae strains isolated from sago palm (Metroxylon sagu) by microbial interaction with non-nitrogen fixers. Microbes Environ. 22: 59-70.

Xie, C.H. and Yokota, A.(2004). Phylogenetic analyses of the nitrogen - fixing genus Derxia.J.Gen.Appl. Microbiol. $50: 129-135$. 